\title{
PENYAJIAN LAPORAN KEUANGAN ENTITAS BERORIENTASI NONLABA BERDASARKAN ISAK 35 PADA MASJID BAITUL HAADI
}

\author{
Sukma Diviana1, Rangga Putra Ananto², Wiwik Andriani ${ }^{3}$, Roni Putra4, \\ Armel Yentifa5 $^{5}$ Zahara ${ }^{6}$, Azi Siswanto ${ }^{7}$ \\ ${ }_{1}^{1} J u r u s a n$ Akuntansi Politeknik Negeri Padang \\ Email:Sukmadiviana9@gmail.com \\ 2 Jurusan Akuntansi Politeknik Negeri Padang \\ Email: rangga@pnp.ac.id \\ ${ }^{3}$ Jurusan Akuntansi Politeknik Negeri Padang \\ Email: wiwikandriani@pnp.ac.id
}

\begin{abstract}
ABSTRAK
Masjid merupakan entitas yang bertujuan tidak untuk mencari laba (entitas nonlaba), sehingga pertanggungjawaban keuangan menjadi aspek penting bagi masjid. Pertanggungjawaban yang baik dapat terwujud dengan melakukan penyajian laporan keuangan masjid yang sesuai dengan standar akuntansi yang berlaku umum. Standar yang mengatur tentang pelaporan keuangan entitas nonlaba adalah Interpretasi Standar Akuntansi Keuangan No. 35 (ISAK 35). Dengan diterapkannya ISAK 35 dalam penyajian laporan keuangan masjid, para pihak yang berkepentingan akan dapat menilai kinerja keuangan masjid. Objek penelitian ini adalah Masjid Baitul Haadi. Data dikumpulkan melalui serangkaian wawancara dan observasi. Sampai saat ini Masjid Baitul Haadi hanya menyajikan laporan keuangan sebatas laporan kas masuk dan kas keluar saja. Penelitian ini bertujuan untuk menyusun laporan keuangan Masjid Baitul Haadi berdasarkan ISAK 35 dengan alat bantu aplikasi Microsoft Excel. Laporan keuangan yang akan dihasilkan adalah laporan Posisi Keuangan, Laporan Penghasilan Komprehensif, Laporan Arus Kas dan Catatan atas Laporan Keuangan.
\end{abstract}

Kata kunci: Masjid, Laporan Keuangan, ISAK 35

\section{ABSTRACT}

Mosque is an entity that aims not for profit (non-profit entity), so that financial accountability becomes an important aspect for mosques. Good accountability can be realized by presenting the mosque's financial reports in accordance with generally accepted accounting standards. The standard governing the financial reporting of non-profit entities is the Interpretation of Financial Accounting Standards No. 35 (ISAK 35). By implementing ISAK 35 in the presentation of mosque financial reports, interested parties will be able to assess the financial performance of the mosque. The object of this research is Mosque Baitul Haadi. Data were collected through a series of interviews and observations. Until now, Mosque Baitul Haadi only presented financial reports as far as cash in and cash out. This study aims to compile the financial statements of Mosque Baitul Haadi based on ISAK 35 using Microsoft Excel application tools. The financial statements that will be produced are the statements of financial position, comprehensive income statements, cash flow statements and notes to financial reports.

Keywords: Mosque, Financial Report, ISAK 35 


\section{PENDAHULUAN}

Entitas nirlaba merupakan entitas yang bergerak dalam bidang pelayanan masyarakat yang tidak bertujuan untuk mencari laba. Entitas nirlaba ini biasanya didirikan oleh masyarakat atau dikelola oleh swasta. Sumber dana yang didapat oleh entitas nirlaba biasanya berasal dari para donator atau penyumbang yang tidak mengharapkan imbal balik atas dana yang diberikan.

Organisasi nirlaba pada umumnya memilih pemimpin, pengurus atau penanggungjawab yang menerima amanat dari para stakeholdernya. Terkait dengan konsep akuntabilitas dimana akuntansi sebagai sarana pertanggungjawaban akuntabilitas maka laporan keuangan perlu disajikan oleh organisasi nirlaba. Alasannya karena dengan laporan keuangan maka dapat menilai pertanggungjawaban dari pengurus/manajemen atas tugas, kewajiban dan kinerja yang diamanatkan kepadanya.

Organisasi nirlaba semenjak tahun 1997 diatur dengan Pernyataan Standar Akuntansi Keuangan (PSAK) 45. Namun mulai tahun 2019 PSAK 45 diganti dengan Interpretasi Standar Akuntansi Keuangan (ISAK) 35. Dengan keluarnya peraturan baru ini maka organisasi nirlaba menyusun laporan keuangannya sesuai dengan ISAK 35. Tapi munculnya peraturan baru ini, terasa sulit untuk diterapkan oleh organisasi nirlaba karena banyak organisasi nirlaba yang tidak memiliki latar belakang ilmu akuntansi sehingga sulit untuk melaksanakannya.

Masjid sebagai salah satu contoh organisasi nirlaba merupakan tempat ibadah bagi umat muslim. Selain masjid digunakan untuk beribadah, masjid juga digunakan untuk belajar Al-Quran, tempat silaturahmi antar umat Islam, tempat berbagi ilmu agama, dan juga masjid digunakan untuk tabungan akhirat yang mana di masjid kita bisa menyisihkan sebagian harta kita untuk disedekahkan dan digunakan untuk pembangunan masjid, menjadi peserta Qurban, maupun kegiatan agama lainnya.

Penyajian laporan keuangan pada masjid seringkali dihadapkan pada dilema antara menjadi lebih profesional dan akuntabel sesuai standar, atau tetap bertahan dengan mengandalkan rasa saling percaya diantara sesama pengurus atau pengelola. Lazimnya secara umum orang berkeinginan untuk menjadi lebih profesional dan tidak menghilangkan rasa saling percaya diantara sesama pengurus atau pengelola yang sudah terjalin selama ini. Dibeberapa kasus yang terjadi adalah pengurus atau pengelola masjid yang tidak mau berubah karena dikhawatirkan akan merusak rasa saling percaya yang kuat selama ini.

Namun sangat disayangkan kita melihat fenomena yang terjadi saat ini bahwa ada masjid yang tidak dapat mengelola keuangannya dengan baik. Kebanyakan masjid hanya mencatat dan melaporkan kas masuk dan kas keluar saja. Masjid tidak melakukan pencatatan invetarisasi terhadap harta yang dimilikinya sehingga nilai ekonomis dari masjid tidak dapat diketahui. Hal ini yang mengunggah kami untuk melakukan kegiatan pengabdian membantu masjid dalam menyajikan laporan keuangannya. Karena kita ketahui bahwa menyusun laporan keuangan bukanlah suatu hal yang mudah apalagi yang sesuai dengan standar. Tim sudah pernah melakukan penyusunan laporan keuangan pada masjid dengan menggunakan standar lama yaitu PSAK 45 (sesuai CV). Dengan adanya pengalaman yang lalu serta adanya tuntutan pedoman yang baru ISAK 35 menjadikan hal ini sangat penting bagi kami untuk melaksanakan kegiatan pengabdian pada masjid karena dapat mengembangkan ilmu untuk proses pembelajaran disamping membantu masjid 
secara khusus dan masyarakat pada umumnya. Harapannya dengan adanya laporan keuangan akan tercipta transparansi dan akuntabilitas dana masjid yang baik yang menjadi keinginan dari masyarakat.

Masjid Baitul Haadi Aur Duri Indah didirikan oleh Masyarakat Aur Duri Indah yang diprakarsai oleh H. Halim Hasan dan Surkanain Makarim. Pada tahun 1983 dengan misi menyelenggarakan dakwah dan pembinaan ummat melalui peningkatan kualitas keimanan dan ketaqwaan serta mengembangkan pendidikan Islam dan pembinaan generasi muda. Masjid Baitul Haadi didirikan diatas lahan Masjid sedangkan perkarangan masjid itu termasuk lahan milik negara, dimana masjid ini dibangun oleh masyarakat asli Aur Duri Indah. Awal pembangunan masjid itu dari sumbangan warga berupa emas, uang dan pinjaman emas warga nantinya pihak pengurus masjid akan mencicil pinjaman tersebut. Dengan berjalannya waktu, pembangunan Masjid cukup berkembang secara signifikan, meskipun pembangunannya belum selesai $100 \%$ masjid tersebut sudah digunakan sebagai tempat ibadah oleh warga sekitar. Ini juga merupakan strategi pengurus pada waktu itu untuk mengumpulkan infak dan sedekah untuk menambah dana pembangunan Masjid dan juga mencicil pinjaman emas warga sekitar. Sejak awal pendirian masjid ini dibangun menjadi dua bangunan, fungsi dari bangunan yang pertama untuk kegiatan Ibadah dan keagamaan, sedangkan bangunan kedua digunakan untuk kegiatan Pendidikan Seperti Pendidikan Al-Quran dan Pendidikan Seni Baca AlQuran.

Masjid ini merupakan masjid yang aktif mengadakan kegiatan-kegiatan keagamaan seperti kegiatan ibadah shalat fardhu berjamaah, shalat jum'at, shalat tarawih, shalat ied dan perayaan hari besar islam seperti isra' mi'raj dan lain sebagainya. Adapun kegiatan lainnya seperti Majelis Ta'lim kegiatan ini merupakan kegiatan pengajian rutin bagi ibu-ibu yang berada di sekitar kawasan Masjid Baitul Haadi. Adapun daya tampung maksimal masjid sebanyak 150 jemaah. Sementara itu untuk kegiatan pemberian santunan kepada anak yatim dibagikan sebanyak 2 kali dalam setahun yaitu ketika Hari Raya Islam Idul Fitri dan saat tahun ajaran baru.

Masjid Baitul Haadi ini memiliki MDA (Madrasah Diniyah Awaliyah) yang jumlah semua murid MDA-nya adalah sebanyak 250 orang. Jumlah siswa yang cukup banyak ini merupakan sumber penerimaan yang besar juga bagi masjid. Dengan ratarata SPP siswa Rp.60.000,- per bulannya. Namun hal ini belum tercatat dalam laporan keuangan yang sesuai standar. Semenjak berdiri sampai saat sekarang belum menyusun laporan keuangan sesuai standar yang telah ditetapkan. Padahal organisasi ini memperoleh dana yang cukup besar dari masyarakat dan juga pemerintah. Laporan yang disajikan hanya secara sederhana saja, hanya mengurangkan uang masuk dengan uang keluar saja. Tidak ada laporan lain yang dibuat oleh Masjid ini, padahal Masjid ini tergolong Masjid yang besar di Kota Padang. Dalam laporan keuangan yang dibuat di atas belum terlihat akuntabilitas dan transparansi terhadap laporan keuangan yang semestinya. Pencatatan terhadap inventarisasi asset belum tergambar dengan baik. Masjid belum pernah membuat daftar aset tetap dan belum pernah menghitung nilai aset tetap beserta penyusutannya, sehingga posisi keuangan yang tercermin dalam catatan keuangan masjid hanya berupa kas saja.

\section{METODE PENELITIAN}




\section{Metode Pengumpulan Data}

Dalam memperoleh data yang dibutuhkan, penulis melakukan penelitian dengan menggunakan metode pengumpulan data sebagai berikut:

\section{a. Tinjauan Literatur}

Penulis melakukan pengumpulan data dengan membaca buku-buku yang tersedia di perpustakaan yang berhubungan dengan permasalahan yang akan dibahas dalam Penelitian ini..

\section{b. Wawancara}

Pada metode ini penulis melakukan wawancara dengan pengurus masjid terutama bendahara masjid untuk mengumpulkan data dengan cara tanya jawab langsung dan berhadapan dengan objek penelitian dan dibantu dengan panduan wawancara sebagai instrumen penelitian.

\section{c. Observasi}

Penulis melakukan pengamatan secara langsung ke entitas yang menjadi subjek penelitian penulis yaitu Masjid Baitul Haadi dan juga melakukan pengumpulan data yang di dapat langsung dari lokasi penelitian itu sendiri.

\section{Metode Analisis Data}

a. Primer

Metode analisis data primer ini dilakukan dengan mendatangi langsung pihak entitas.

b. Sekunder

Peninjauan lapangan dilakukan dengan cara mengunjungi langsung ke Masjid Baitul Hadi untuk mendapatkan data yang dibutuhkan dalam penelitian.

\section{TINJAUAN PUSTAKA}

\section{Pengertian Akuntansi}

Definisi akuntansi menurut American Accounting Association (AAA) dalam Dwi Harti (2009:4) adalah proses mengidentifikasikan, mengukur, dan melaporkan informasi ekonomi, untuk memungkinkan adanya penilaian dan keputusan yang jelas dan tegas bagi mereka yang menggunakan informasi tersebut. Sedangkan Akuntansi menurut American Institute of Certified Public Accountant (AICPA) adalah proses pencatatan, penggolongan, dan peringkasan transaksi kejadian yang tepat (berdaya guna) dalam bentuk satuan uang dan penafsiran hasil proses tersebut.

Menurut Soemarso S.R (2009:3) akuntansi adalah media komunikasi, oleh karena itu sering disebut sebagai "bahasanya dunia usaha" (business of language). Akuntansi akan menghasilkan informasi yang berguna baik bagi pihak-pihak yang menyelenggarakannya maupun pihak-pihak luar. Kegunaan tersebut terutama berhubungan dengan proses pengambilan keputusan dan pertanggungjawaban. Definisi lain menurut Rusdianto (2012:16) akuntansi adalah aktivitas 
mengumpulkan, menganalisis, menyajikan dalam bentuk angka, mengklasifikasikan, mencatat, meringkas dan melaporkan aktivitas/transaksi perusahaan dalam bentuk informasi keuangan. Sedangkan menurut S. Carl Warrent, dkk (2017:3) akuntansi adalah sistem informasi yang menyediakan laporan untuk para pemangku kepentingan mengenai aktivitas ekonomi dan kondisi perusahaan. Sistem informasi mengumpulkan dan memproses data-data yang berkaitan dan kemudian menyebarkan informasi keuangan kepada pihak yang tertarik. Akuntansi adalah "bahasa bisnis" (language of business) karena melalui akuntansi lah informasi bisnis dikomunikasikan kepada para pemangku kepentingan.

Menurut PSAK 1 (Ikatan Akuntan Indonesia, 2018) Entitas nonlaba merupakan entitas yang memperoleh sumber daya dari pemberi sumber daya yang tidak mengharapkan pembayaran kembali atau manfaat ekonomik yang sebanding dengan jumlah sumber daya yang diberikan. Entitas nonlaba ini biasanya didirikan oleh masyarakat atau dikelola oleh swasta. Sumber dana yang didapat oleh entitas nonlaba biasanya berasal dari para donator atau penyumbang yang tidak mengharapkan imbal balik atas dana yang diberikan.

Jadi akuntansi adalah proses mengidentifikasi, mengukur dan melaporkan informasi ekonomi yang berguna untuk pengambilan keputusan bagi para pemangku kepentingan mengenai aktivitas ekonomi dan kondisi perusahaan.

\section{Siklus Akuntansi}

Siklus akuntansi pada entitas nonlaba hampir sama dengan siklus akuntansi pada umumnya. Menurut Halim dan Kusufi (2013), siklus akuntansi dikelompokkan dalam tiga tahap, adalah sebagai berikut :

a) Tahap pencatatan, terdiri dari kegiatan pengidentifikasian dan pengukuran dalam bentuk transaksi dan buku pencatatan, kegiatan pencatatan bukti transaksi ke dalam buku jurnal, dan memindah bukukan (posting) dari jurnal berdasarkan kelompok atau jenisnya ke dalam akun buku besar.

b) Tahap pengikhtisaran, terdiri dari penyusunan neraca saldo berdasarkan akun-akun buku besar, pembuatan ayat jurnal penyesuaian, penyusunan kertas kerja, pembuatan ayat jurnal penutup, membuat neraca saldo setelah penutupan, membuat ayat jurnal pembalik.

c) Tahap pelaporan, yang terdiri dari Laporan posisi keuangan, laporan penghasilan komperhensif, laporan arus kas dan catatan atas laporan keuangan.

\section{Konsep Dasar ISAK 35}

Pada tanggal 11 April 2019 Dewan Standar Akuntansi Keuangan Ikatan Akuntansi Indonesia telah mengesahkan ISAK 35 (Interpretasi Standar Akuntansi Keuangan) yang mengatur tentang penyajian laporan keuangan entitas beriorientasi nonlaba yang berlaku efektif untuk periode tahun buku yang dimulai pada tanggal 1 Januari 2020. Dimana sebelumnya untuk organisasi nonlaba diatur dengan Pernyataan Standar Akuntansi Keuangan 45 (PSAK 45) revisi 2017 yang sekarang telah diganti 
menjadi ISAK 35. PSAK 45 dengan ISAK 35 terdapat perbedaan, dimana perbedaan yang mendasar yaitu klasifikasi aset neto, yang mana menggabungkan aset neto terikat permanen dan aset neto terikat temporer menjadi aset neto dengan pembatasan (with restrictions) akan mengurangi kompleksitas dan aset neto tidak terikat menjadi aset neto tanpa pembatasan (without restrictions), oleh karena itu akan membawa pemahaman yang lebih baik dan manfaaat lebih besar bagi pengguna laporan keuangan entitas berorientasi nonlaba.

Interpreasi Standar Akuntansi Keuangan (ISAK 35) menjelaskan perincian penyajian laporan keuangan entitas berorientasi nonlaba yang telah disajikan seperti berikut:

1. PSAK 1 : Penyajian Laporan Keuangan paragraf 05 menyatakan bahwa "Pernyataan ini menggunakan terminologi yang cocok bagi entitas yang berorientasi laba, termasuk entitas bisnis sektor publik. Jika entitas dengan aktivitas nonlaba di sektor swasta atau sektor publik menerapkan Pernyataan ini, maka entitas tersebut mungkin perlu menyesuaikan deskripsi yang digunakan untuk beberapa pos yang terdapat dalam sendiri." Dengan demikian, ruang lingkup PSAK 1 secara substansi telah mencakup ruang lingkup penyajian laporan keuangan entitas dengan aktivitas nonlaba

2. PSAK 1 : Penyajian Laporan Keuangan tidak menyediakan pedoman bagaimana entitas dengan aktivitas nonlaba menyajikan laporan keuangannya. Entitas dengan aktivitas nonlaba dalam Interpretasi ini selanjutnya merujuk kepada entitas berorientasi nonlaba.

3. Karakteristik entitas berorientasi nonlaba berbeda dengan entitas bisnis berorientasi laba. Perbedaan utama yang mendasar antara entitas berorientasi nonlaba dengan entitas bisnis berorientasi laba terletak pada cara entitas berorientasi nonlaba memperoleh sumber untuk melakukan berbagai aktivitas operasinya. Entitas berorientasi nonlaba memperoleh sumber daya dari yang tidak mengharapkan pembayaran kembali atau manfaat ekonomik yang sebanding dengan jumlah sumber daya yang diberikan.

4. Pengguna laporan keuangan entitas berorientasi nonlaba umumnya memiliki kepentingan untuk menilai: (a) cara manajemen melaksanakan tanggung jawab atas penggunaan sumber daya yang dipercayakan kepada mereka; serta (b) informasi mengenai posisi keuangan, kinerja keuangan dan arus kas entitas yang bermanfaat dalam pembuatan keputusan ekonomik. Kemampuan entitas berorientasi nonlaba dalam menggunakan sumber daya tersebut dikomunikasikan melalui laporan keuangan.

\section{Ruang Lingkup :}

1. Interpretasi ini diterapkan untuk entitas berorientasi nonlaba terlepas dari bentuk badan hukum entitas tersebut.

2. Interpretasi ini diterapkan juga oleh entitas berorientasi nonlaba yang menggunakan Standar Akuntansi Keuangan Entitas Tanpa Akuntabilitas Publik (SAK ETAP).

3. Interpretasi ini diterapkan khusus untuk penyajian laporan keuangan.

\section{Permasalahan}


Interpretasi ini membahas bagaimana entitas berorientasi nonlaba membuat penyesuaian baik:

(a) penyesuaian deskripsi yang digunakan untuk beberapa pos dalam laporan keuangan; dan

(b) penyesuaian deskripsi yang digunakan untuk laporan keuangan itu sendiri.

\section{Interpretasi}

1. Penyajian laporan keuangan entitas berorientasi nonlaba disusun dengan memperhatikan persyaratan penyajian laporan keuangan, struktur laporan keuangan dan persyaratan minimal isi laporan keuangan yang telah diatur dalam PSAK 1: Penyajian Laporan Keuangan.

2. Entitas berorientasi nonlaba dapat membuat penyesuaian deskripsi yang digunakan untuk beberapa pos yang terdapat dalam laporan keuangan. Sebagai contoh, jika sumber daya yang diterima oleh entitas berorientasi nonlaba mengharuskan entitas untuk memenuhi kondisi yang melekat pada sumber daya tersebut, entitas dapat menyajikan jumlah sumber daya tersebut berdasarkan sifatnya, yaitu pada adanya pembatasan (with restrictions) atau tidak adanya pembatasan (without restrictions) oleh pemberi sumber daya.

3. Entitas berorientasi nonlaba juga dapat menyesuaikan deskripsi yang digunakan atas laporan keuangan itu sendiri. Sebagai contoh, penyesuaian atas penggunaan judul 'laporan perubahan aset neto' daripada 'laporan perubahan ekuitas'. Penyesuaian atas judul laporan keuangan tidak dibatasi sepanjang penggunaan judul mencerminkan fungsi yang lebih sesuai dengan isi laporan keuangannya.

4. Entitas berorientasi nonlaba tetap harus mempertimbangkan seluruh fakta dan keadaan relevan dalam menyajikan laporan keuangannya termasuk catatan atas laporan keuangan, sehingga tidak mengurangi kualitas informasi yang disajikan dalam laporan keuangan.

\section{Tanggal Efektif}

Entitas menerapkan Interpretasi ini untuk periode tahun buku yang dimulai pada atau setelah tanggal 1 Januari 2020.

\section{Ruang Lingkup dan Permasalah ISAK 35}

a) Ruang lingkup ISAK 35: Penyajian Laporan Keuangan Entitas Berorientasi Nonlaba memberikan pedoman penyajian laporan keuangan untuk entitas berorientasi nonlaba sebagai Interpretasi dari PSAK 1: Penyajian Laporan Keuangan Paragraf 05.

b) Interpretasi ini diterapkan juga oleh entitas berorientasi nonlaba yang menggunakan Standar Akuntansi Keuangan Entitas Tanpa Akuntabilitas Publik (SAK ETAP).

c) Perundang-undangan di Indonesia yang mengatur secara spesifik mengenai definisi dan ruang lingkup entitas berorientasi nonlaba tidak ditemukan. Oleh karena itu, DSAK IAI tidak memberikan definisi atau kriteria untuk membedakan entitas berorientasi nonlaba dari entitas bisnis berorientasi laba.

d) Entitas melakukan penilaiannya sendiri untuk menentukan apakah entitas merupakan suatu entitas berorientasi nonlaba, terlepas dari bentuk badan hukum 
entitas tersebut, sehingga dapat menerapkan Interpretasi ini. Beberapa faktor yang dapat dipertimbangkan entitas adalah:

(a) apakah sumber daya entitas berorientasi nonlaba berasal dari pemberi sumber daya yang tidak mengharapkan pembayaran kembali atau manfaat ekonomik yang sebanding dengan jumlah sumber daya yang diberikan;

(b) menghasilkan barang dan/atau jasa tanpa bertujuan memupuk laba, dan jika entitas berorientasi nonlaba menghasilkan laba, maka jumlahnya tidak dibagikan kepada pendiri atau pemilik entitas berorientasi nonlaba tersebut;

(c) tidak ada kepemilikan seperti umumnya pada entitas bisnis berorientasi laba, dalam arti bahwa kepemilikan dalam entitas berorientasi nonlaba tidak dapat dijual, dialihkan atau ditebus kembali atau kepemilikan tersebut tidak mencerminkan proporsi pembagian sumber daya entitas berorientasi nonlaba pada saat likuidasi atau pembubaran entitas berorientasi nonlaba.

\section{Laporan Keuangan Entitas Nonlaba Berdasarkan ISAK 35}

Menurut PSAK 1 (Ikatan Akuntan Indonesia, 2018) laporan keuangan adalah suatu penyajian terstruktur dari posisi keuangan dan kinerja keuangan suatu entitas. Selain itu, laporan keuangan ini juga merupakan hasil akhir dari siklus akuntansi. Tujuan dibuatnya laporan keuangan adalah untuk memberikan informasi mengenai posisi keuangan, kinerja keuangan dan arus kas entitas yang bermanfaat bagi sebagian besar pengguna laporan keuangan dalam pembuatan keputusan ekonomik. Laporan keuangan juga menunjukkan hasil pertanggungjawaban manajemen atas penggunaan sumber daya yang dipercayakan kepada mereka.

Laporan keuangan menyajikan informasi mengenai entitas yang meliputi aset, liabilitas, ekuitas, pendapatan beban termasuk keuntungan dan kerugian, kontribusi dari dan kontribusi kepada pemilik dan arus kas yang disertakan dengan informasi lainnya yang terdapat dalam catatan atas laporan keuangan. Berdasarkan ISAK 35, laporan keuangan yang dihasilkan dari siklus akuntansi entitas berorientasi nonlaba antara lain: laporan posisi keuangan, laporan penghasilan komprehensif, laporan perubahan aset neto, laporan arus kas, dan catatan atas laporan keuangan.

Berikut contoh dari laporan keuangan entitas nonlaba:

\section{1) Laporan Posisi Keuangan}

Laporan yang menggambarkan posisi aset, liabilitas dan aset bersih pada waktu tertentu. Berikut penulis akan menguraikan tentang tujuan laporan posisi keuangan, klasifikasi aset dan liabilitas, klasifikasi aset neto tanpa pembatasan dan aset neto dengan pembatasan. Tujuan laporan posisi keuangan adalah untuk menyediakan informasi mengenai aset, liabilitas dan aset neto serta informasi mengenai hubungan antara unsur-unsur tersebut pada waktu tertentu. Laporan keuangan entitas mencakup secara keseluruhan dan menyajikan total aset, liabilitas, dan aset neto. Laporan keuangan entitaas dapat digambarkan sebagai berikut:

a) Aset

Sumber daya yang dikuasai entitas sebagai akibat dari peristiwa masa lalu dan dari mana manfaat ekonomi dimasa depan diharapkan akan diperoleh entitas (IAI, 2011). 
Pada umumnya entitas menyajikan dan mengumpulkan aset kelompok yang homogen. Diantaranya adalah:

a. Kas dan setara kas

b. Piutang pasien, pelajar, anggota, dan penerima jasa lain

c. Persediaan

d. Sewa, asuransi, dan jasa lain yang dibayar dimuka

e. Instrumen keuangan dan investasi jangka panjang

f. Tanah,gedung,peralatan, serta aset tetap lain yang digunakan untuk menghasilkan barang jasa

b) Liabilitas

Liabilitas merupakan klaim dari pihak ketiga atas aset entitas. Liabilitas disusun berdasarkan urutan jatuh tempo dari liabilitas/kewajiban tersebut. Kewajiban yang akan jatuh tempo kurang dari satu tahun digolongkan kewajiban lancar, sedangkan kewajiban yang akan jatuh tempo lebih dari satu tahun digolongkan kepada kewajiban jangka panjang. Contoh urutan dan penyajian liabilitas/kewajiban adalah:

a. Utang

b. Pendapatan Diterima Dimuka

c. Utang Lainnya

d. Utang Jangka Panjang

c) Aset Neto

Dalam laporan keuangan komersial, aset neto dikenal sebagai modal. Laporan posisi keuangan menyajikan jumlah masing-masing kelompok aset neto berdasarkan pada ada atau tidaknya pembatasan oleh pemberi sumber daya yang tidak mengharapkan pembayaran kembali. Aset neto neto berdasarkan kondisi yang melekat pada sumber daya menjadi dua klasifikasi aset neto yaitu:

a. Aset Neto Tanpa Pembatasan (without restrictions).

Aset neto tanpa pembatasan adalah aset neto yang tidak ada batasan terhadap aset tersebut, misalnya sumbangan yang diberikan oleh si donatur, dimana donatur tidak secara jelas mencantumkan jangka waktu dari donasinya tadi hanya untuk memberikan donasi untuk entitas tersebut sehingga pemasukan dan pengeluaran yang berhubungan dengan entitas dapat mempergunakannya untuk kebutuhan entitas.

b. Aset Neto Dengan Pembatasan (with restrictions).

Aset neto dengan pembatasan, menggabungkan klasifikasi aset neto terikat permanen dan aset neto terikat temporer menjadi aset neto dengan pembatasan akan mengurangi kompleksitas. Aset neto dengan pembatasan adalah aset neto yang berkaitan dengan sumber daya berupa aktivitas operasi tertentu, investasi untuk jangka waktu tertentu, dan aset neto yang digunakan untuk selamanya, seperti tanah dan bangunan yang diberikan untuk tujuan tertentu, sehingga pemasukan dan pengeluarannya itu diluar entitas seperti kas anak yatim, kas fakir miskin dan lain lain.

Terdapat 2 (dua) format Laporan Posisi Keuangan yang disajikan :

1. Format A menyajikan informasi pos penghasilan komprehensif lain secara tersendiri sebagai bagian dari aset neto tanpa pembatasan dari pemberi sumber daya. Akan tetapi, jika penghasilan komprehensif lain berasal dari aset 
neto dengan pembatasan, maka entitas menyajikan informasi penghasilan komprehensif lain tersebut sesuai dengan kelas aset netonya

2. Format B tidak menyajikan informasi pos penghasilan komprehensif lain secara tersendiri.

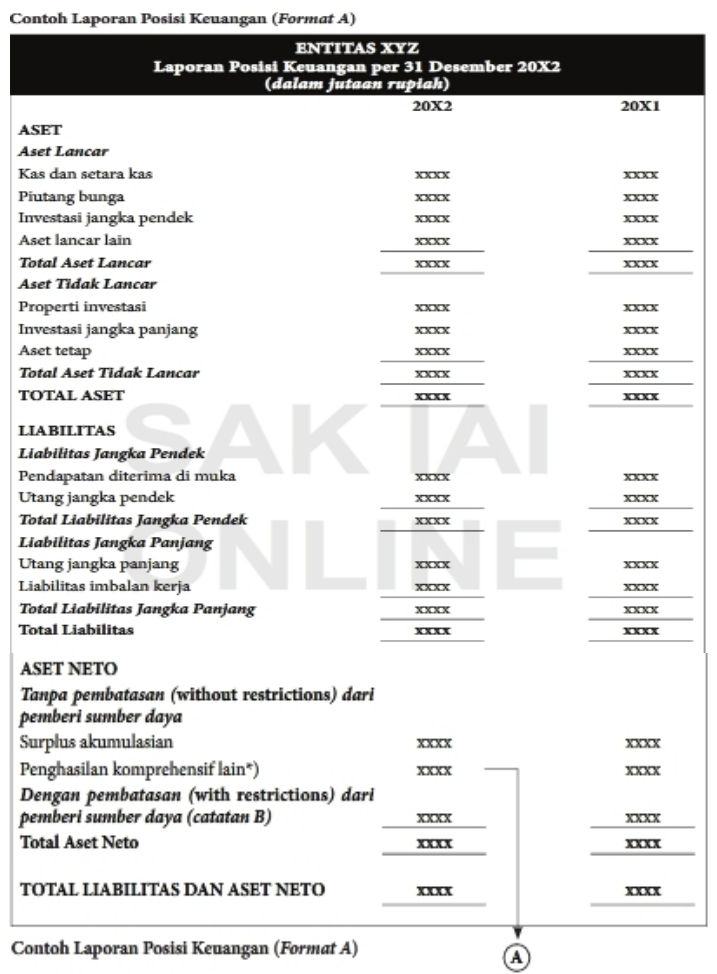

Gambar 1. Bentuk Laporan Posisi Keuangan A Sumber: SAK IAI ONLINE (ISAK 35)

Contoh Laporan Posisi Keuangan (Format B)

\begin{tabular}{|c|c|c|}
\hline \multicolumn{3}{|c|}{$\begin{array}{c}\text { ENTITAS XYZ } \\
\text { Laporan Posis Keuangan per } 31 \text { Desember } 20 \times 2 \\
\text { (dalam jufaan rupiah) }\end{array}$} \\
\hline & $20 \times 2$ & 20X1 \\
\hline \multicolumn{3}{|l|}{ ASET } \\
\hline \multicolumn{3}{|l|}{ Aset Lancar } \\
\hline Kas dan setara kas & $x x x x$ & $x x x x$ \\
\hline Piutang bunga & $x x x x$ & $x x x x$ \\
\hline Investasi jangka pendek & $x x x x$ & $x x x x$ \\
\hline Aset lancar lain & $x x x x$ & $x x x$ \\
\hline Total Aset Lancar & $x x x x$ & $x x x x$ \\
\hline \multicolumn{3}{|l|}{ Aset Tidak Lancar } \\
\hline Properti investasi & $x x x x$ & $x x x x$ \\
\hline Investasi jangka panjang & $x x x x$ & $\operatorname{xxx} x$ \\
\hline Aset tetap & $x x x x$ & $x x x$ \\
\hline Total Aset Tidak Lancar & $x x x$ & $x x x x$ \\
\hline TOTAL ASET & $x \times x$ & $x x x$ \\
\hline \multicolumn{3}{|l|}{ LIABILITAS } \\
\hline \multicolumn{3}{|l|}{ Liabilitas Jangka Pendek } \\
\hline Pendapatan diterima di muka & $x x x x$ & $x x x$ \\
\hline Utang jangka pendek & $x x x x$ & $x x x x$ \\
\hline Total Liabilitas Jangka Pendek & $x x x$ & $x x x x$ \\
\hline \multicolumn{3}{|l|}{ Liabilitas Jangka Panjang } \\
\hline Utang jangka panjang & $x x x$ & $x x x x$ \\
\hline Liabilitas imbalan kerja & $x x x$ & $x x x x$ \\
\hline Total Liabilitas Jangka Panjang & $x x x x$ & $x x x x$ \\
\hline Total Liabilitas & $x x x$ & $x x x$ \\
\hline
\end{tabular}




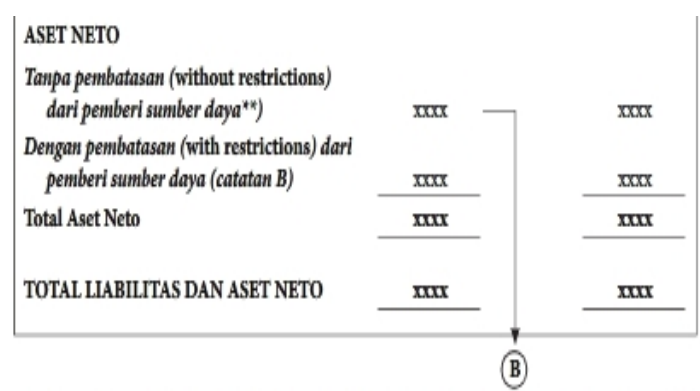

Gambar 2. Bentuk Laporan Posisi Keuangan B Sumber: SAK IAI ONLINE (ISAK 35)

\section{2) Laporan Penghasilan Komprehensif}

Laporan yang menyajikan laporan laba rugi untuk suatu periode yang merupakan kinerja keuangan selama periode tersebut. Dimana laporan ini juga mengatur informasi yang disajikan dalam laporan laba rugi seperti penghasilan dan beban entitas untuk suatu periode

Informasi yang disajikan dalam laporan laba rugi:

a) Pendapatan

b) Beban keuangan

c) Bagian laba atau rugi dari investasi yang menggunakan metode ekuitas

d) Beban pajak

e) Laba rugi atau rugi neto

Laporan Penghasilan Komprehensif

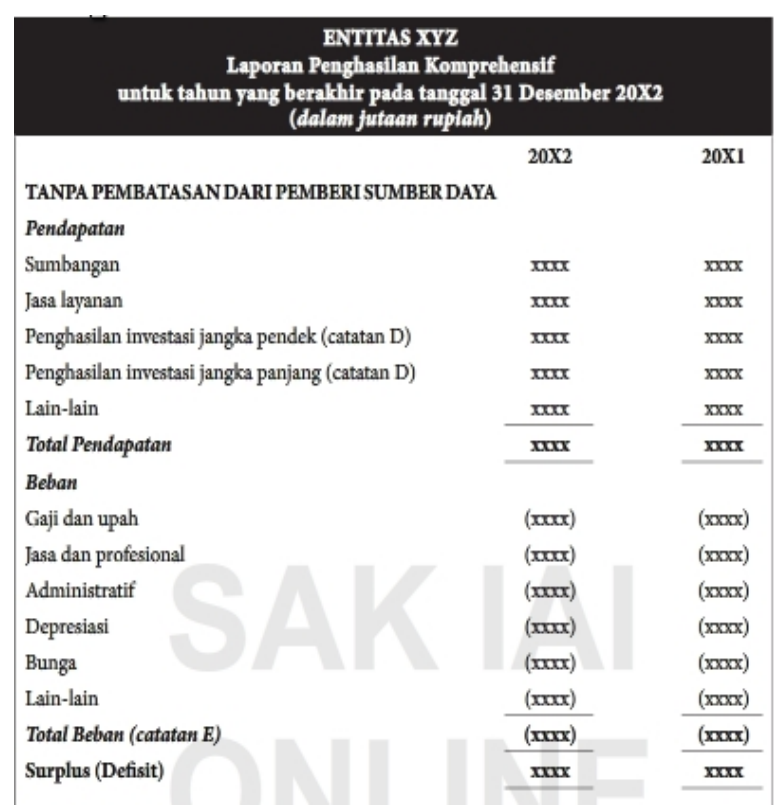




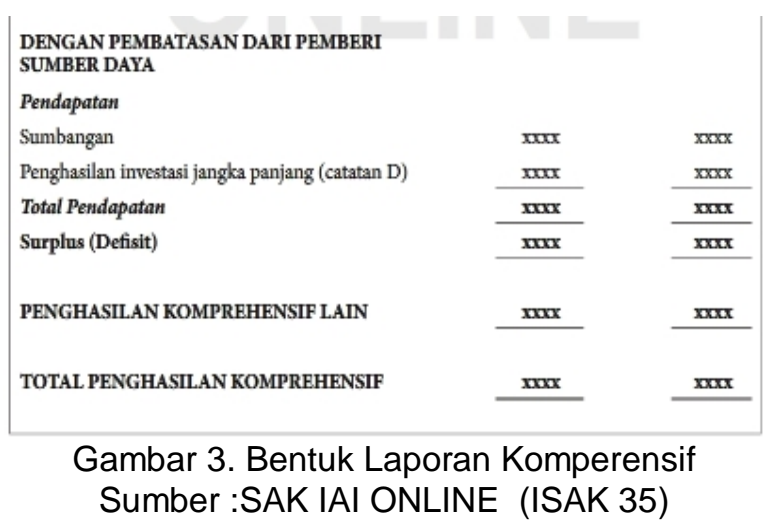

\section{3) Laporan perubahan Aset Neto}

Dalam penyusunan laporan keuangan berdasarkan interprestasi standar akuntansi keuangan (ISAK 35) merupakan laporan perubahan aset neto menyajikan informasi aset neto tanpa pembatasan dari pemberi sumber daya dan aset neto dengan pembatasan dari pemberi sumber daya. Berikut contoh laporan perubahan aset neto:

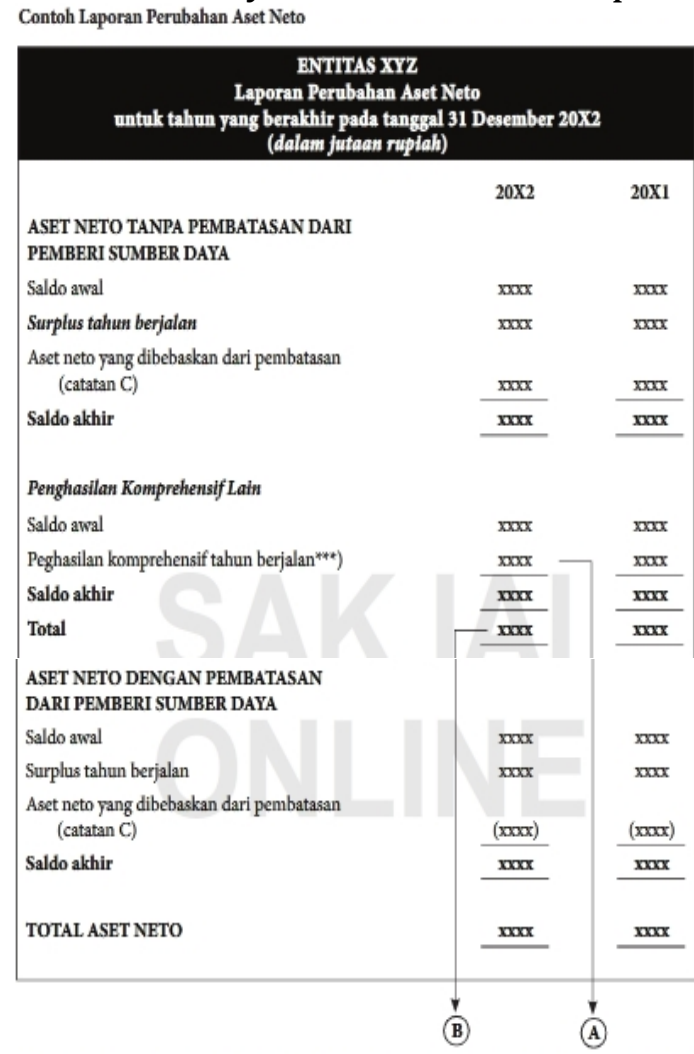

Gambar 4. Bentuk Laporan Perubahan Aset Neto Sumber: SAK IAI ONLINE (ISAK 35)

\section{4) Laporan Arus Kas}

Laporan arus kas adalah laporan yang menunjukkan penerimaan dan pengeluaran kas dan setara kas selama periode tertentu yang dikelompokan dalam aktivitas operasional, aktivitas investasi dan aktivitas pendanaan. Informasi tentang arus kas berguna bagi para pengguna laporan keuangan sebagai dasar untuk menilai kemampuan masjid dalam menghasilkan kas dan setara kas serta menilai kebutuhan 
pengguna arus kas tersebut. Laporan arus kas disajikan sesuai dengan dasar pengaturan SAK ETAP Bab 7 dengan tambahan berikut ini:

1. Aktivitas Operasi

Aktivitas penghasil utama pendapatan dan aktivitas lain yang bukan merupakan aktivitas investasi dan aktivitas pendanaan.

2. Aktivitas Investasi

Aktivitas perolehan dan pelepasan aset jangka panjang serta investasi lain yang tidak termasuk setara kas.

3. Aktivitas Pendanaan

Penerimaan kas dari pemberi sumber daya yang tidak mengharapkan pembayaran kembali yang penggunaannya dibatasi dalam jangka panjang, Penerimaan kas dari pemberi sumber daya dan penghasilan investasi yang penggunaannya dibatasi untuk pembangunan dan pemeliharaan aset tetap, atau peningkatan dana abadi dan imbal hasil dan dividen yang dibatasi penggunanya dalam jangka panjang

Adapun bentuk Laporan Arus Kas yang disajikan dengan metode tidak langsung menurut ISAK No. 35 adalah sebagai berikut:

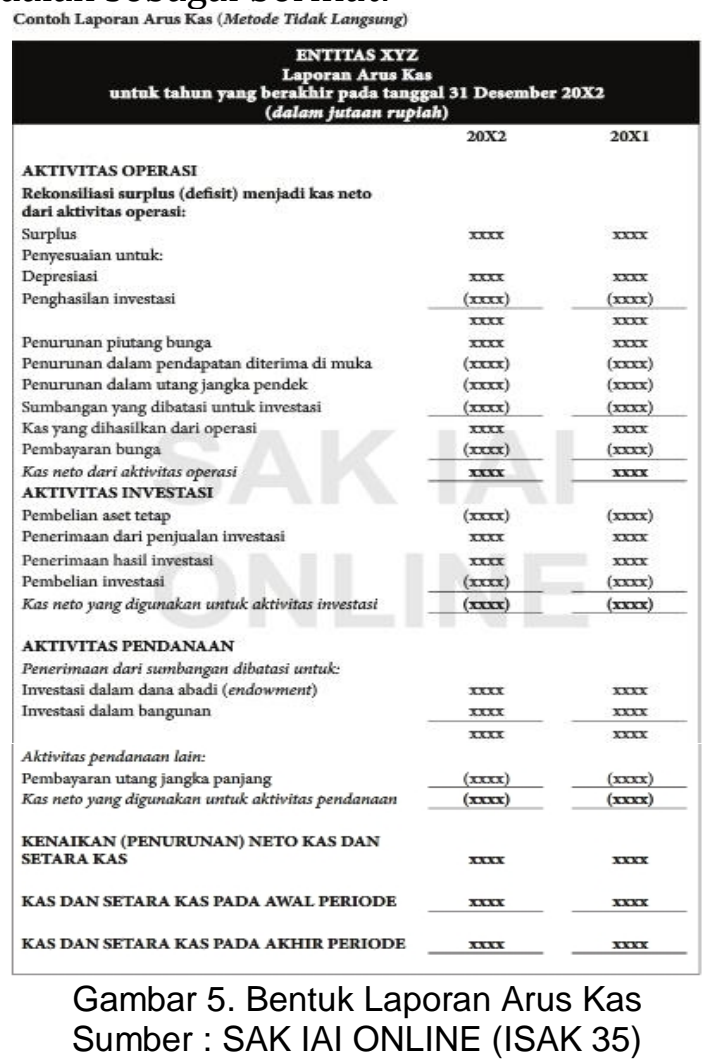

\section{5) Catatan Atas Laporan Keuangan}

Catatan atas laporan keuangan merupakan bagian yang tidak terpisah dari laporanlaporan di atas. Bertujuan memberikan informasi tambahan tentang perkiraanperkiraan yang diyatakan dalam laporan keuangan. Catatan atas laporan keuangan ini berupa perincian dari suatu perkiraaan yang disajikan seperti misalnya aset tetap. Catatan atas laporan keuangan memberikan rincian nama aset, liabilitas, aset neto. Misalnya, untuk aset tetap di catatan atas laporan keuangan akan dijelaskan untuk 
menghitung penyusutan aset tetap, serta kebijakan akuntansi lainnya yang digunakan oleh entitas tersebut.

\section{HASIL DAN PEMBAHASAN}

Berdasarkan hasil dari penelitian, terdapat beberapa data yang dapat dikumpulkan, sehingga menghasilkan laporan keuangan sebagai berikut:

1. Laporan Penghasilan Komprehensif

Pada Laporan Pnghasilan Komprehensif dapat dilihat pada kolom Perubahan Aset Neto terdapat penambahan (pengurangan) masing-masing aset neto pada akhir periode. Namun pada bulan Januari 2020 aset neto Masjid Baitul Haadi secara keseluruhan mengalami penurunan dapat dilihat pada kolom total penghasilan komprehensif. Pada awal Januari 2020 total aset neto adalah Rp 10.204.730.106 sedangkan akhir Januari 2020 total aset neto mengalami penurunan menjadi Rp 10.200.145.550

\begin{tabular}{|l|l|l|r|}
\hline \multicolumn{5}{|c}{ MESJID BAITUL HAADI } \\
\hline \multicolumn{4}{|c|}{ LAPORAN PENGHASILAN KOMPREHENSIF } \\
\hline \multicolumn{1}{|c|}{ UNTUK PERIODE YANG BERAKHIR BULAN JANUARI 2020 } \\
\hline TANPA PEMBATASAN DARI PEMBERI & & & \\
SUMBER DAYA & & TP & - \\
\hline PENDAPATAN TANPA PEMBATASAN & & TP & - \\
\hline Pendapatan Infak Mesjid & $2 \mathrm{~g}, 9$ & TP & 9.249 .000 \\
\hline Pendapatan Donatur & $2 \mathrm{~g}, 9$ & TP & 12.045 .000 \\
\hline Pendapatan Bagi Hasil Mesjid & $2 \mathrm{~g}, 9$ & TP & 3.224 \\
\hline Total Pendapatan Tanpa Pembatasan & & & $\mathbf{2 1 . 2 9 7 . 2 2 4}$ \\
\hline BEBAN-BEBAN & & - & - \\
\hline BEBAN TANPA PEMBATASAN & & TP & - \\
\hline Beban Honor Petugas Mesjid & $2 \mathrm{~g}, 11$ & TP & 2.700 .000 \\
\hline Beban Honor Ustadz & $2 \mathrm{~g}, 11$ & TP & 4.650 .000 \\
\hline Beban Petugas Kebersihan & $2 \mathrm{~g}, 11$ & TP & 400.000 \\
\hline Beban Adminitrasi Kas bank mesjid & $2 \mathrm{~g}, 11$ & TP & 6.500 \\
\hline Beban Transportasi Ustadz & $2 \mathrm{~g}, 11$ & TP & 2.200 .000 \\
\hline Beban Listrik & $2 \mathrm{~g}, 11$ & TP & 2.715 .040 \\
\hline Beban Reparasi & $2 \mathrm{~g}, 11$ & TP & 300.000 \\
\hline Beban Speedy & $2 \mathrm{~g}, 11$ & TP & 390.500 \\
\hline Beban Fotocopy & $2 \mathrm{~g}, 11$ & TP & \\
\hline Beban Air & $2 \mathrm{~g}, 11$ & TP & 34.700 \\
\hline Beban Loundry & $2 \mathrm{~g}, 11$ & TP & 25.000 \\
\hline Beban Operasional Mesjid & $2 \mathrm{~g}, 11$ & TP & 259.850 \\
\hline \multicolumn{1}{|c|}{ Total Beban Tanpa Pembatasan } & & & $\mathbf{1 3 . 6 8 1 . 5 9 0}$ \\
\hline Surplus (Defisit) Tanpa Pembatasan & & & $\mathbf{7 . 6 1 5 . 6 3 4}$ \\
\hline DENGAN PEMBATASAN DARI PEMBERI & & & \\
\hline SUMBER DAYA & & & \\
\hline PENDAPATAN DENGAN PEMBATASAN & & DP & \\
\hline Pendapatan Infak Anak Yatim & $2 \mathrm{~g}, 10$ & DP & 15.250 .000 \\
\hline Pendapatan Bagi Hasil Anak Yatim & $2 \mathrm{~g}, 10$ & DP & 8.667 \\
\hline Pendapatan Bagi Hasil Fakir Miskin & $2 \mathrm{~g}, 10$ & DP & 4.226 \\
\hline Pendapatan MDTA & $2 \mathrm{~g}, 10$ & DP & 8.403 .000 \\
\hline Pendapatan Infak Fakir Miskin & $2 \mathrm{~g}, 10$ & DP & 9.427 .000 \\
\hline Pendapatan Infak Remaja Mesjid & $2 \mathrm{~g}, 10$ & DP & 1.750 .000 \\
\hline Total Pendapatan Dengan Pembatasan & & & $\mathbf{3 4 . 8 4 2 . 8 9 3}$ \\
\hline & & & $\mathbf{5 6 . 1 4 0 . 1 1 7}$ \\
\hline
\end{tabular}




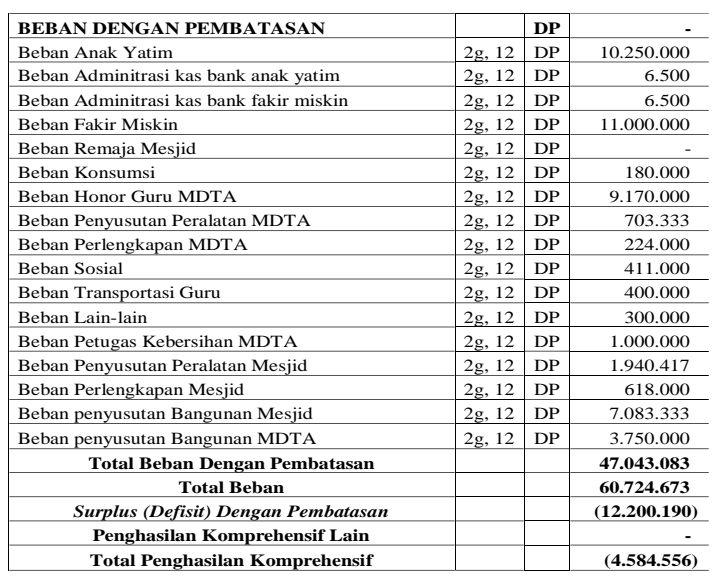

Gambar 6. Laporan Penghasilan Komprehensif Sumber : Masjid Baitul Haadi

2. Laporan Perubahan Aset Neto

Laporan perubahan aset neto merupakan laporan yang memberikan informasi mengenai perubahan aset neto yang terjadi di suatu entitas nonlaba. Di dalam laporan perubahan aset neto terdapat dua kelompok aset neto yaitu, aset neto tanpa pembatasan dan aset neto dengan pembatasan. Pada laporan ini dapat diperoleh informasi mengenai surplus atau defisit aset neto dalam suatu periode. Berikut laporan perubahan aset neto Masjid Baitul Haadi bulan Januari 2020:

\begin{tabular}{|l|r|}
\hline \multicolumn{2}{|c|}{ MESJID BAITUL HAADI } \\
\hline \multicolumn{2}{|c|}{ LAPORAN PERUBAHAN ASET NETO } \\
\hline \multicolumn{2}{|c|}{ UNTUK PERIODE YANG BERAKHIR BULAN JANUARI 2020 } \\
\hline Aset Neto Tanpa Pembatasan Dari Pemberi Sumber Daya & \\
\hline Saldo Awal & $\mathbf{3 3 . 2 2 4 . 9 6}$ \\
\hline Surplus tahun berjalan & 7.615 .63 \\
\hline Saldo Akhir & $\mathbf{4 0 . 8 4 0 . 5 9}$ \\
\hline & \\
\hline Aset Neto Dengan Pembatasan Dari Pemberi Sumber Daya & 10.171 .505 .14 \\
\hline Saldo Awal & $(12.200 .19$ \\
\hline Surplus(Defisit) tahun berjalan & $\mathbf{1 0 . 1 5 9 . 3 0 4 . 9 5}$ \\
\hline Saldo Akhir & $\mathbf{1 0 . 2 0 0 . 1 4 5 . 5 5}$ \\
\hline \multicolumn{2}{|c|}{} \\
\hline TOTAL ASET NET0 & \\
\hline \multicolumn{2}{|c|}{} \\
\hline \multicolumn{2}{|c|}{ Gambar 7. Laporan Perubahan Aset Neto } \\
Sumber : Masjid Baitul Haadi
\end{tabular}

\section{Laporan Posisi Keuangan}

Laporan posisi keuangan masjid, menggambarkan aset (harta), liabilitas (utang) dan aset neto (modal) Masjid. Dalam laporan posisi keuangan kita dapat melihat saldo akhir dari kas masjid, total nilai aset dari masjid, dn juga dapat melihat liabilitas yang harus di penuhi oleh masjid. Untuk saldo akhir aset neto, nilai nya diambil dari laporan penghasilan komprehensif yang mana telah mengalami kenaikan atau penurunan.

Berikut laporan posisi keuangan Masjid Baitul Haadi bulan Januari 2020: 


\begin{tabular}{|c|c|}
\hline \multicolumn{2}{|c|}{$\begin{array}{c}\text { MESJID BAITUL HAADI } \\
\text { LAPORAN POSISI KEUANGAN }\end{array}$} \\
\hline Aset & \\
\hline ASET LANCAR & \\
\hline Kas dan Setara Kas & 127.914 .987 \\
\hline Perlengkapan Mesjid & 19.964 .000 \\
\hline Perlengkapan Pendidikan/MDTA & 1.240 .000 \\
\hline Total Aset Lancar & 149.118.987 \\
\hline ASET TIDAK LANCAR & - \\
\hline Tanah & 8.640 .000 .000 \\
\hline Bangunan Mesjid & 1.700 .000 .000 \\
\hline Akm.Penyusutan Bangunan Mesjid & $(913.750 .000)$ \\
\hline Bangunan MDTA & 900.000 .000 \\
\hline Akm.Penyusutan Bangunan MDTA & $(435.000 .000)$ \\
\hline Peralatan Mesjid & 220.405 .000 \\
\hline Akm.Penyusutan Peralatan Mesjid & $(81.747 .396)$ \\
\hline Peralatan MDTA & 50.950 .000 \\
\hline Akm.Penyusutan Peralatan MDTA & $(29.831 .042)$ \\
\hline $\begin{array}{c}\text { Total Aset Tidak Lancar } \\
\end{array}$ & 10.051 .026 .563 \\
\hline Total ASET & 10.200 .145 .550 \\
\hline LIABILITAS & - \\
\hline Utang Entitas & - \\
\hline Utang Gaji & - \\
\hline Total Liabilitas & - \\
\hline ASET NETO & - \\
\hline Aset Neto Tanpa Pembatasan & 40.840 .594 \\
\hline Aset Neto Dengan Pembatasan & 10.159.304.956 \\
\hline $\begin{array}{c}\text { Total Aset Neto } \\
\end{array}$ & 10.200 .145 .550 \\
\hline TOTAL LIABILITAS DAN ASET NETO & 10.200 .145 .550 \\
\hline
\end{tabular}

Gambar 8. Laporan Posisi Keuangan Sumber : Masjid Baitul Haadi

4. Laporan Arus Kas

Tujuan dibuatnya Laporan Arus Kas adalah untuk melihat saldo kas akhir suatu entitas, dan melihat arus kas (cash flow) pemasukan dan pengeluaran. Laporan arus kas hanya menunjukan kas masuk dan kas keluar saja, jika tidak sama dengan saldo kas yang ada dalam laporan posisi keuangan, kemungkinan terjadi salah catat. Berikut laporan arus kas Masjid Baitul haadi bulan Januari 2020:

\section{Masjid Baitul Haadi \\ Laporan Arus Kas \\ Untuk Periode Yang Berakhir Bulan Januari 2020}

(Disajikan dalam Rupiah) 


\begin{tabular}{|c|c|}
\hline Aktivitas Operasi & \\
\hline Rekonsiliasi surplus (defisit) menjadi kas neto dari aktivitas operasi: & \\
\hline Perubahan dalam aset neto & $(4.584 .556)$ \\
\hline $\begin{array}{l}\text { Penyesuaian untuk rekonsiliasi dalam aset neto menjadi kas neto } \\
\text { yang digunakan untuk aktivitas operasi: }\end{array}$ & \\
\hline Ditambah: & \\
\hline Beban Penyusutan Peralatan Mesjid & 1.940 .417 \\
\hline Beban Penyusutan Peralatan MDTA & 703.333 \\
\hline Beban Penyusutan Bangunan Mesjid & 7.083 .333 \\
\hline Beban Penyusutan Bangunan MDTA & 3.750 .000 \\
\hline Penurunan perlengkapan Mesjid & 141.000 \\
\hline Penurunan Perlengkapan MDTA & 224.000 \\
\hline \begin{tabular}{|l} 
Kas Neto yang diterima dari Kegiatan Operasi \\
\end{tabular} & 9.257 .527 \\
\hline Aktivitas Investasi & - \\
\hline & - \\
\hline Kas Neto Yang Diterima (digunakan) untuk Aktivitas Investasi & - \\
\hline & - \\
\hline Aktivitas Pendanaan & - \\
\hline & - \\
\hline $\begin{array}{l}\text { Kas Neto Yang Diterima (digunakan) untuk Aktivitas } \\
\text { Pendanaan }\end{array}$ & - \\
\hline $\begin{array}{l}\text { KENAIKAN (PENURUNAN)ASET NETO DALAM KAS DAN } \\
\text { SETARA KAS }\end{array}$ & 9.257 .527 \\
\hline KAS DAN SETARA KAS PADA AWAL BULAN & 118.657 .460 \\
\hline KAS DAN SETARA KAS PADA AKHIR BULAN & 127.914.987 \\
\hline
\end{tabular}

Gambar 9. Laporan Arus Kas

Sumber : Masjid Baitul Haadi

\section{Catatan Atas Laporan Keuangan}

Catatan atas laporan keuangan merupakan bagian tak terpisahkan dari laporan keuangan masjid. Catatan atas laporan keuangan memuat penjelasan mengenai gambaran umum masjid, ikhtisar kebijakan akuntansi, penjelasan pos-pos laporan keuangan dan informasi penting lainnya. Catatan atas laporan keuangan disajikan secara sistematis. Setiap pos dalam laporan posisi keuangan, laporan penghasilan komprehensif, dan laporan arus kas harus berkaitan dengan informasi yang ada dalam catatan atas laporan keuangan.

\section{Neraca Saldo Setelah Penutupan}

Neraca Saldo setelah penutupan adalah saldo akhir suatu periode pencatatan akuntansi yang akan menjadi neraca awal diperiode selanjutnya. Neraca saldo akhir merupakan neraca saldo yang dibuat setelah akun nominal ditutup sehingga yang tinggal dalam neraca saldo akhir adalah akun rill saja. Berikut neraca saldo periode Januari 2020 yang akan digunakan untuk neraca saldo awal periode berikutnya yaitu Februari 2020 : 


\begin{tabular}{|c|c|c|}
\hline \multicolumn{3}{|c|}{ MESJID BAITUL HAADI } \\
\hline \multicolumn{3}{|c|}{ Neraca Saldo Setelah Penutupan } \\
\hline & Per & $31 / 01 / 2020$ \\
\hline \multicolumn{3}{|l|}{ Aset } \\
\hline \multicolumn{3}{|l|}{ ASET LANCAR } \\
\hline Kas dan Setara Kas & $\begin{array}{ll}\mathrm{Rp} & 127.914 .987\end{array}$ & \\
\hline Perlengkapan Mesjid & Rp $\quad 19.964 .000$ & \\
\hline Perlengkapan Pendidikan/MDTA & $\begin{array}{ll}\mathrm{Rp} & 1.240 .000\end{array}$ & \\
\hline \multicolumn{3}{|l|}{ ASET TIDAK LANCAR } \\
\hline Tanah & Rp 8.640 .000 .000 & \\
\hline Bangunan Mesjid & Rp 1.700 .000 .000 & \\
\hline Akm.Penyusutan Bangunan Mesjid & & 913.750 .000 \\
\hline Bangunan MDTA & Rp $\quad 900.000 .000$ & \\
\hline Akm.Penyusutan Bangunan MDTA & & $\mathrm{Rp} \quad 435.000 .000$ \\
\hline Peralatan Mesjid & $\begin{array}{ll}\mathrm{Rp} & 220.405 .000 \\
\end{array}$ & \\
\hline Akm.Penyusutan Peralatan Mesjid & & 81.747 .396 \\
\hline Peralatan MDTA & 50.950 .000 & \\
\hline Akm.Penyusutan Peralatan MDTA & & 29.831 .042 \\
\hline \multicolumn{3}{|l|}{ LIABILITAS } \\
\hline Utang Entitas & $\mathrm{Rp}$ & \\
\hline Utang Gaji & $\mathrm{Rp}$ & \\
\hline \multicolumn{3}{|l|}{ ASET NETO } \\
\hline Aset Neto Tanpa Pembatasan & & $\mathrm{Rp} \quad 40.840 .594$ \\
\hline Aset Neto Dengan Pembatasan & & $\operatorname{Rp} 10.159 .304 .956$ \\
\hline Total & Rp 11.660.473.987 & Rp11.660.473.987 \\
\hline
\end{tabular}

\section{KESIMPULAN DAN SARAN}

\section{Kesimpulan}

Berdasarkan analisis dan uraian masalah pada bab sebelumnya, maka dapat penulis simpulkan beberapa hal sebagai berikut:

1. Penyusunan laporan Penghasilan Komprehensif yang memperlihatkan kenaikan dan penurunan dari aset neto, Laporan Posisi Keuangan yang memperlihatkan nilai dari aset, kewajiban serta aset neto Masjid Baitul Haadi per 31 Januari dan 29 Februari, Laporan Arus Kas yang berisi penggunaan kas dari aktivitas operasi, aktivitas pendanaan serta aktivitas investasi dan Catatan Atas Laporan Keuangan Masjid Baitul Haadi yang berisi informasi umum, kebijakan akuntansi serta rincian perhitungan untuk setiap akun yang dimiliki Masjid Baitul Haadi.

2. Penyusunan laporan Keuangan berdasarkan ISAK No. 35 dapat menyajikan perubahan aset neto, dan menyajikan naik turunnya aset neto selama periode tertentu, sehingga ini bisa dijadikan sebagai penilaian kinerja Masjid Baitul Haadi. Selain itu, juga dapat menyajikan laporan arus kas masjid selama periode tertentu, yang melaporkan penerimaan dan pengeluaran kas selama periode tertentu. Berikut hasil kinerja Masjid Baitul Haadi:

a. Bulan Januari 2020

a) Penurunan Aset Neto bulan Januari 2020 sebesar Rp 4.584 .556

b) Total Aset Neto Akhir Tanpa Pembatasan per 31 Januari 2020 adalah Rp 40.840.594

c) Total Aset Neto Akhir Dengan Pembatasan per 31 Januari 2020 adalah Rp 10.159.304.956

d) Posisi Keuangan per 31 Januari 2020 adalah Rp 10.200.145.550

e) Kenaikan Neto dalam Kas sebesar Rp 9.257.527

f) Kas Akhir per 31 Januari 2020 adalah Rp 127.914.987 
b. Bulan Februari 2020
a) Penurunan Aset Neto bulan Februari 2020 sebesar Rp 41.915 .786
b) Total Aset Neto Akhir Tanpa Pembatasan per 29 Februari 2020 adalah Rp 28.862.978
c) Total Aset Neto Akhir Dengan Pembatasan per 29 Februari 2020 adalah Rp 10.129.366.786
d) Posisi Keuangan per 29 Februari 2020 adalah Rp 10.158.229.764
e) Penurunan Neto dalam kas sebesar Rp 44.884 .723
f) Kas Akhir per 29 Februari 2020 adalah Rp 83.030.264

\section{Saran}

Dengan adanya penelitian ini diharapkan pihak Masjid Baitul Haadi dapat mencatat pelaporan keuangan sesuai dengan standar yang berlaku yaitu ISAK No. 35 tujuannya agar kita bisa melihat bagaimana laporan posisi keuangan masjid yang sebenarnya

\section{DAFTAR PUSTAKA}

Warrent, dkk. 2017. Pengantar Akuntansi Adaptasi Indonesia. Edisi 25. Jakarta: Salemba Empat.

Rudianto. 2012. Pengantar Akuntansi Konsep dan Teknik Penyusunan Laporan Keuangan. Jakarta: Erlangga.

Halim Abdul, Muhammad Syam Kusufi. 2013. Teori, Konsep, dan Aplikasi Akuntansi Sektor Publik. Jakarta: Salemba Empat.

Harahap, Sofyan Syafri. 2007. Teori Akuntansi, edisi revisi 09, Jakarta: PT Raja Grafindo Persada, Jakarta

Ikatan Akuntan Indonesia. 2018. Pedoman Akuntansi Keuangan. Jakarta.

SAK Ikatan Akuntan Indonesia Online. ISAK 35. Penyajian Laporan Keuangan Entitas Berorientasi Nonlaba per 1 Januari 2020. Jakarta.

Ikatan Akuntan Indonesia. 2017. Standar Akuntansi Keuangan per 1 Januari 2017. Jakarta.

Ikatan Akuntan Indonesia, 2016. Standar Akuntansi Keuangan per 1 Januari 2016. Jakarta.

S.R, Soemarso. 2009. Akuntansi Suatu Pengantar Buku 1 Edisi 5. Jakarta: Salemba Empat.

Ikatan Akuntan Indonesia. 2011. Standar Akuntansi Keuangan Entitas Tanpa Akuntabilitas Publik. Jakarta.

Ikatan Akuntan Indonesia. 2011. Pernyataan Standar Akuntansi Keuangan Nomor 109. Jakarta: IA 
ISSN 2657-1080

ISSN 1858-3687

Akuntansi dan Manajemen Vol.15, No.2, 2020

Ikatan Akuntan Indonesia. (2018). Draft Eksposur Pernyataan Standar Akuntansi Keuangan (DE PSAK) 112 tentang Akuntansi Wakaf

Bastian, Indra. 2007. Akuntansi Yayasan Dan Lembaga Publik. Jakarta: PT Erlangga 